九州大学学術情報リポジトリ

Kyushu University Institutional Repository

\title{
Characteristic Water Status in Dwarf Pea in Relation to Drought Resistance
}

Inoue, Mari

Laboratory of Crop Science, Division of Agricultural Botany, Department of Plant

Resoruces, Faculty of Agriculture, Kyushu University

\section{Iwaya Mar $\mathrm{i}$}

Motooka, Ke i

Laboratory of Horticultural Science, Department of Agronomy, Graduate School of Agriculture, Kyushu University

Ishibashi, Yushi

Laboratory of Crop Science, Division of Agricultural Botany, Department of Plant

Resoruces, Faculty of Agriculture, Kyushu University

他

https://doi.org/10.5109/4523

出版情報：九州大学大学院農学研究院紀要. 48 (1/2)，pp. 29-38，2003-10-01. Faculty of Agriculture, Kyushu University

バージョン：

権利関係 : 


\title{
Characteristic Water Status in Dwarf Pea in Relation to Drought Resistance
}

\author{
Mari IWAYA-INOUE ${ }^{\dagger}$, Kei MOTOOKA*, Yushi ISHIBASHI** and \\ Masataka FUKUYAMA
}

\author{
Laboratory of Crop Science, Division of Agricultural Botany, Department of Plant Resources, \\ Faculty of Agriculture, Kyushu University, Fukuoka 812-8581, Japan \\ (Received June 29, 2003 and accepted July 15, 2003)
}

\begin{abstract}
Dwarfism in pea (Pisum sativum L.) manifests itself more conspicuously in the light, and light-induced epicotyl growth inhibition in relation to water status was studied. NMR spin-lattice relaxation times $\left(T_{1}\right)$ s of epicotyls of no-elongation zone were markedly longer than those of elongation zone of the seedlings of both cultivars, tall type cv. Alaska and dwarf type, cv. Progress No. 9. $T_{1}$ of $\mathrm{GA}_{1}$-dose response in dwarf pea, which grows normally, decreased in elongation zone while $T_{1} \mathrm{~s}$ in no-elongation zone increased. The changes in $T_{1}$ of light-and dark-grown pea epicotyls were not simply attributable to a change in water content. Water of dwarf control and no-elongation zone of $\mathrm{GA}_{1}$-treated cv. Progress No. 9 grown under light condition was more sustained during three-hours air drying compared to those of cv. Alaska. Osmotic concentrations in elongation zones were higher than those of no-elongation zone. In addition, there was no relationship between osmotic concentration and cell length. It seems that the epicotyl tissues of dwarf pea phenotype were high $T_{1}$ values accompanied by low osmotic values while water uptake was not changed. In conclusion, $T_{1}$ of the pea seedlings will be useful for an evaluation of the dwarfism and $\mathrm{GA}_{1}$ dose-response to drought stress.
\end{abstract}

\section{INTRODUCTION}

Many dwarf varieties of plants are defective in gibberellin (GA) biosynthesis or sensitivity. A dwarf cultivar of pea plant (Pisum sativum L.) appeared to be manifest only in red light while its growth resembled that of tall cultivar when it was grown in complete darkness. Red light suppresses the growth of the shoots of pea seedlings via a phytochrome-mediated response (Sponcel, 1986). Large content of A-2 $\alpha$ and A-2 $\beta$ in cv. Progress in the steady state under continuous red light, compared with that in cv. Alaska, may explain the dwarfism of cv. Progress (Noguchi and Hashimoto, 1990). They stated that A-2s were responsible for red light-induced growth inhibition in cv. Progress No. 9. GAs are endogenous regulators of plant growth. Therefore, the inhibition of stem elongation of pea seedlings by light irradiation was also associated with a decrease in the level of $\mathrm{GA}_{1}$. It has been shown that GA regulates elongation, in both light- and dark-grown hypocotyls in GA-deficient and altered GA-response mutants of Arabidopsis

\footnotetext{
* Laboratory of Horticultural Science, Department of Agronomy, Graduate School of Agriculture, Kyushu University; present address, Kumamoto prefecture government, Hitoyoshi City.

** Laboratory of Crop Science, Division of Agricultural Botany, Department of Plant Resources, Graduate School of Bioresource and Bioenvironmental Sciences, Kyushu University

${ }^{+}$Corresponding author (E-mail: mariino@agr.kyushu-u.ac.jp)
} 
thaliana (L.) Heyhn cells (Cowling and Harberd, 1999).

GA increased total amount of osmotic solutes in leaf sheath of a dwarf mutant of rice (Oryza sativa L. cv. Tan-ginbozu) but did not increase the osmotic concentration of the cell sap, due to an accompanying increase in cell volume by water absorption (Matsukura et al., 1998). Growth of plants is attributed to cell elongation driven by water absorption by cell and cell wall extension (Lockhart, 1965a, b). Water absorption to the cell is governed by the growth-induced water potential (Molz and Boyer, 1978; Nonami and Boyer, 1987; 1993; Nonami et al., 1997; Ikeda et al., 1999a, b). In parenchyma cells, the volume of water occupies $90 \%$ or over. Since many metabolic processes occur in aqueous solution in cells, the water in living tissues is considered to play an important role in their physiological condition. Nuclear magnetic resonance (NMR) can be demonstrated to detect the dynamic states of water. Spin-lattice relaxation time $\left(T_{1}\right)$ and spin-spin relaxation time $\left(T_{2}\right)$ indicate the water status in tissues since they reflect the motion of water molecules. In previous reports, relationship between water content and NMR relaxation times $\left(T_{1}\right.$ or $\left.T_{2}\right)$ of water protons has been observed in cold-acclimated red osier dogwood stems (Burke et al., 1974), azalea flower buds (Kaku et al.,1984), winter wheat (Yoshida et al., 1997) and wilting flowers (Iwaya-Inoue and Nonami, 2003). Furthermore, the NMR has been applied to the studies of plant tissues that are exposed to environmental stresses (Iwaya-Inoue et al., 1993; Ishida et al., 2000). However, there have been few reports about the role of water in relation to the dwarfism. In addition, it is stated that expression of turgor-responsive gene varies with respect to a time course of induction and reversibility of the wilting-induced changes in shoots of light-grown pea cv. Progress No. 9 (Guerrero et al., 1990).

This paper presents changes in $T_{1}$ in epicotyls of tall and dwarf cultivars of pea and $\mathrm{GA}_{1}$-dose response under dehydration stress. Factors influencing on water status of dwarf pea were also discussed.

\section{MATERIALS AND METHODS}

\section{Plant materials}

Tall type of pea (Pisum sativum L.) cv. Alaska obtaining from commercial sources was used. Furthermore, seeds of dwarf genotype, cv. Progress No. 9, were provided by Dr. M. Katsumi. Two cultivars of pea were cultivated in a growth cabinet (Koitotron HNB-10A) at about $22^{\circ} \mathrm{C}$ with dark condition or with a photoperiod of $14 \mathrm{~h} \mathrm{light} / 10 \mathrm{~h}$ dark. Fluorescent lamps (FLR20S W/M 20W $\times 4$ ) were used as a luminous source. 10 to 12 day-old seedlings were used as materials. $100 \mu \mathrm{M} \mathrm{GA}_{1}$ was sprayed on an apex of 5 day-old seedlings of cv. Progress No. 9 grown under light condition. Epicotyls of the 2nd node from the apex part as elongation zone or basal part as no-elongation zone were cut from the intact pea seedlings and they were used following experiments.

\section{Measurements of proton $T_{1}$ relaxation times}

Epicotyl tissues (each about $20 \mathrm{~mm}$ in length) were packed into a $7.5 \mathrm{~mm}$ diameter NMR tube. NMR measurements were made at $20 \mathrm{MHz}$ on a Bruker Minispec PC20 pulsed NMR spectrometer as described previously (Iwaya-Inoue et al., 1993). The $T_{1}$ values of epicotyls were measured by inversion recovery method using a $180^{\circ}-\tau-90^{\circ}$ pulse 
sequence (Farrar and Becker, 1971). $T_{1}$ determination was done 10 to 15 times for each sample. The probe temperature was controlled by a thermostat (Lauda Kryo-SK65) connected to the sample chamber of the spectrometer. Determination was carried out at $20^{\circ} \mathrm{C}$.

\section{Air-drying treatment and measurement of water content of epicotyls}

Changes in water content and $T_{1}$ were measured by air-drying piece of epicotyls for $30 \mathrm{~min}$ to $3 \mathrm{~h}$. Air-drying of section of the tissues was performed by placing the sample on nylon mesh at room temperature (about $26^{\circ} \mathrm{C}$ ). Fresh and dry weights of epicotyls were obtained after drying in an oven at $80^{\circ} \mathrm{C}$ for $24 \mathrm{~h}$. Water content was expressed as the amount of water to dry weight.

\section{Determination of osmotic concentration}

Cortex tissues of epicotyls for both cultivars were placed in a series of sucrose solutions. After a treatment period, cells in the sections were examined for plasmolysis under a microscope. The water loss causes a decrease of the protoplast cell volume and eventually leads to plasmolysis. The percentage of plasmolyzed cells in each solution was plotted against the sucrose concentration. The concentration that caused $50 \%$ plasmolysis was obtained from the graph and was estimated as osmotic value of individual tissues.

\section{RESULTS AND DISCUSSION}

\section{Effects of light on cell length and epicotyl growth of pea cultivars}

Epicotyl length of pea (Pisum sativum L.) dwarf type, cv. Progress No. 9 grown under light condition was about $40 \mathrm{~mm}$ while those of tall type, cv. Alaska ranged between 80 and $150 \mathrm{~mm}$ (Fig. 1). Under dark condition, the epicotyl of dwarf cv. Progress No. 9 grew well and the length of intact epicotyls was between 130 and $200 \mathrm{~mm}$ while cv. Alaska epicotyls grew in a range $260-300 \mathrm{~mm}$. It was indicated that red light inhibited the shoot elongation of cv. Progress No. 9 much more than that of cv. Alaska, and the elongation of cv. Progress No. 9 during $48 \mathrm{~h}$ was $23 \%$ that of cv. Alaska (Kato-Noguchi, 2002). He described that difference in GA $3 \beta$-hydroxylase between $\mathrm{cv}$. Alaska and the dwarf pea was one replacement of alanine with threonine, which may affect the activity of the enzyme. The growth of epicotyl was dependent upon cell length in cvs. Alaska and Progress No. 9 (Fig. 1). Cell length of cortex parenchyma was responsible for the epicotyl growth. $\mathrm{GA}_{1}$ specifically promoted epicotyl growth of $\mathrm{cv}$. Progress No. 9 grown under light condition (data not shown). A-2 $\alpha$ and $A-2 \beta$ may be responsible for the red-light-induced growth inhibition of the dwarf pea seedlings (Kato-Noguchi and Hashimoto, 1997/98). In embryo of Brassica napus L. reduced growth of axis treated by uniconazole, GA inhibitor, was due to reduced cell elongation, but not cell number, and the co-applied $\mathrm{GA}_{1}$ thus prevented the uniconazole-induced reduction in cell length (Hays et al., 2002)

It has been shown that GA regulates elongation, in both light- and dark-grown hypocotyls by influencing the rate and final extent of cellular elongation in GA-deficient and altered GA-response mutants of Arabidopsis thaliana (L.) Heyhn cells (Cowling 


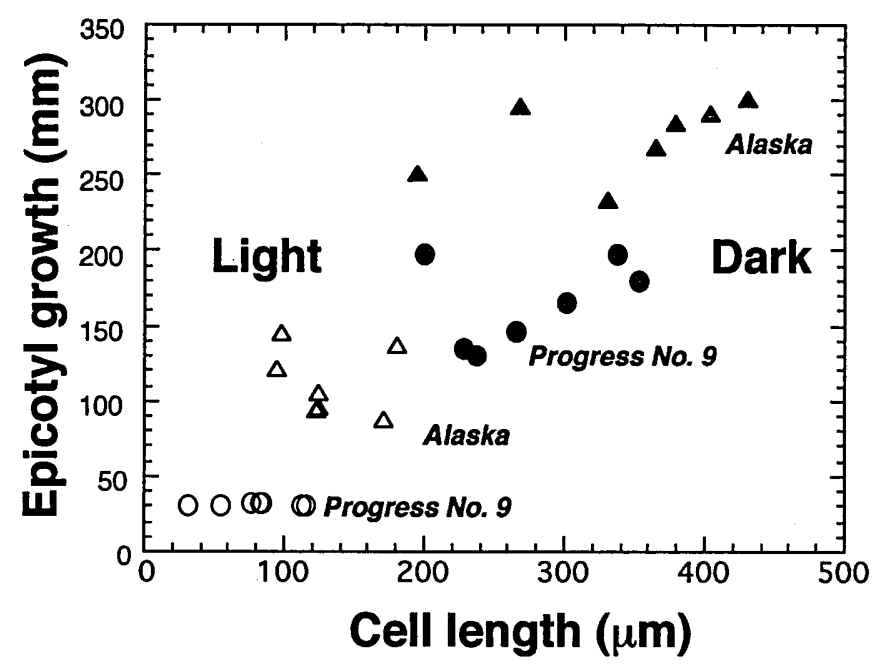

Fig. 1. Relationship between cell length and epicotyl growth of pea (Pisum sativum L.) cultivars. Seedlings of Alaska $(\triangle, \boldsymbol{\Delta})$ and Progress No. 9 $(\bigcirc$, ) were grown under light (open symbols) and dark conditions (closed symbols). 10 to 12 day-old seedlings were used.

and Harberd, 1999). However, light- and dark-grown hypocotyls exhibited markedly different GA dose-response relationships. The length of dark-grown hypocotyls was relatively unaffected by exogenous GA, while light-grown hypocotyl length was significantly increased by the GA-dose. Further analysis suggested that GA control of hypocotyl length was close to saturation in dark-grown hypocotyls, but not in light-grown hypocotyls. These results indicated that a large range of possible hypocotyl lengths is achieved via dose-dependent GA-regulated alterations in the degree of elongation of individual hypocotyl cells (Cowling and Harberd, 1999).

\section{The relationship between $T_{1}$ values and water contents}

Since water in pea epicotlys accounts for more than $95 \%$ of their fresh weight, NMR signals from non-water protons could be ignored in the following experiment. The relationship between $T_{1}$ values and water contents for epicotyls of cvs. Alaska and Progress No. 9 grown at dark condition is shown in Fig. 2A. $T_{1}$ s for elongation zone ranged between about 0.4 and $0.7 \mathrm{~s}$ while those for no-elongation zone were between about 0.9 and $1.3 \mathrm{~s}$ in both tall and dwarf cultivars. Epicotyls of no-elongation zone of both cultivars indicated markedly higher $T_{1}$ values than those of elongation zone of these genotypes and there was no difference in these cultivars. On the other hand, water contents of both elongation and no-elongation zone were between 17 and $22 \mathrm{~g} \mathrm{H}_{2} \mathrm{O}$ g dry $\mathrm{wt}^{-1}$. The water content did not relate to $T_{1}$ value. Under light condition a marked difference of $T_{1}$ between cvs. Alaska and Progress No. 9 was observed in these seedlings (Fig. 2B). $T_{1}$ values of cv. Progress No. 9, which mainly consisted of no-elongation zone, 

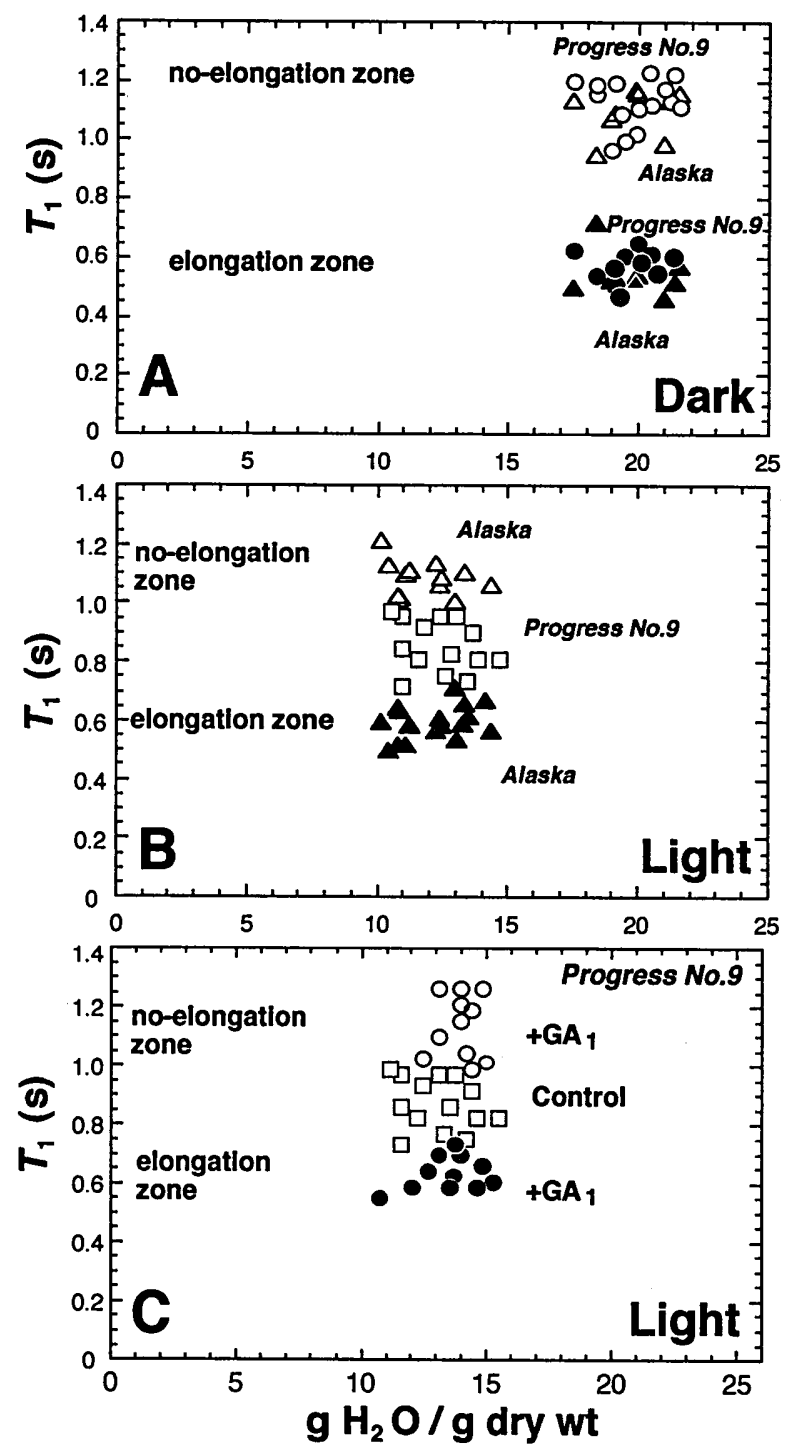

Fig. 2. Relationship between water content and $T_{1}$ in epicotyls of pea cultivars. (A) Elongation zone of dark-grown seedlings of cv. Alaska ( $\boldsymbol{\Delta}$ ) and cv. Progress No. $9(\mathbf{O})$; no-elongation zone of dark-grown seedlings of $\mathrm{cv}$. Alaska $(\triangle)$ and $c v$. Progress No. $9(\mathrm{O})$. (B) Elongation zone of light-grown seedlings of $\mathrm{cv}$. Alaska $(\boldsymbol{A})$; no-elongation zone of light-grown seedlings of $\mathrm{cv}$. Alaska $(\triangle)$ and those of $\mathrm{cv}$. Progress No. 9 ( $\square$ ). (C) Effect of $\mathrm{GA}_{1}$ on light-grown seedlings of cv. Progress No. 9. Elongation zone (O) and no-elongation zone $(O)$ of $\mathrm{GA}_{1}$-treated seedlings and control seedlings without $\mathrm{GA}_{1}(\square) .100 \mu \mathrm{M} \mathrm{GA}_{1}$ was sprayed on apex of 5 day-old seedlings. 
ranged between those of both elongation zone and no-elongation zone of cv. Alaska. On the other hand, water content ranged between 10 and $15 \mathrm{~g} \mathrm{H}_{2} \mathrm{Og}$ dry wt $\mathrm{wt}^{-1}$ and there was no difference among three groups. Water contents of light-grown epicotyls were $5 \mathrm{~g}$ $\mathrm{H}_{2} \mathrm{Og}$ dry $\mathrm{wt}^{-1}$ less than those of dark-grown seedlings (Fig. 2A). Present results indicated that higher water content was related to epicotyl growth but not to $T_{1}$ values.

Additionally, exogenous $\mathrm{GA}_{1}$ on cv. Progress No. 9 seedlings grown under light condition induced shoot growth, and it caused markedly changes in $T_{1}$ (Fig. 2C). Decreased $T_{1}$ of $\mathrm{GA}_{1}$-dose response was observed in elongation zone while increased $T_{1} \mathrm{~S}$ were observed in no-elongation zone in the dwarf pea. There was also no clear relationship between $T_{1}$ value and water content. From these results, $T_{1}$ values and water contents of $\mathrm{GA}_{1}-$ dose response in the dwarf pea were almost same range in those of no-elongation zone and elongation zone of cv. Alaska, respectively (Fig. 2B, C). Although a marked correlation between $T_{1}$ and water content was observed in woody plant leaves (Kaku et al., 1990), the present studies suggested that the change in $T_{1}$ of light- and dark-grown pea epicotyls was not simply attributable to a change in water content.

\section{Influence of dehydration on $T_{1}$ in epicotyls}

$\mathrm{GA}_{1}$-dose response on $T_{1}$ and water content was studied by air-drying piece of light-grown dwarf pea. $T_{1}$ and water content of epicotyls gradually decreased with air-drying in cvs. Alaska and Progress No. 9 (Fig. 3A). The gradient was the smallest in the elongation zone of $\mathrm{cv}$. Alaska and those of $\mathrm{GA}_{1}$-treated cv. Progress No. 9 seedling exposed to dehydration stress, and it was indicated that relationship between $T_{1}$ and water content was almost same. The fact is supported that $T_{1}$ decreased linearly with the decrease in water content of air-drying woody plant leaves (Kaku et al., 1992) and Vigna radiata hypocotyls (Iwaya-Inoue et al., 1993). Further, water loss was more enhanced in the elongation zone of both cv. Alaska and $\mathrm{GA}_{1}$-treated cv. Progress No. 9, and no-elongation zone of cv. Alaska (Fig. 3B). On the other hand, water of dwarf control and no-elongation zone of $\mathrm{GA}_{1}$-treated cv. Progress No. 9, which was cultivated under light condition, was more sustained during three-hours air drying compared to those of cv. Alaska. However, dwarf type of tall fescue (Festuca arundinaces Schreb) indicated more drought-sensitive than tall type based on reductions in relative water content and leaf water potential (Huang et al., 1998). In general, cells of well-watered plants maintain a turgor pressure of 0.4 to $0.8 \mathrm{MPa}$. Increase in ABA in dehydrated pea shoots could only be detected after $0.5 \mathrm{~h}$-dehydration to zero turgor (Guerrero and Mullet, 1988). From these results, dwarf type was drought resistant compared to tall phenotype even when cv. Progress No. 9 was treated by $\mathrm{GA}_{1}$.

\section{Causative factors affecting $T_{1}$ prolongation in dwarfism}

It was indicated that high water content was related to epicotyl growth but not to $T_{1}$ values (Figs. 1 and 2). Thus, other factors besides water content seem to lead to the prolongation of relaxation times in the dwarfism. Water absorption to the cell is governed by the growth-induced water potential (difference of water potential between the water source and the elongating cells) (Molz and Boyer, 1978; Nonami and Boyer, 1987; 1993; Nonami et al., 1997; Ikeda et al., 1999a, b). Osmotic concentrations in elongation zone were higher than those in no-elongation zone (Fig. 4). In addition, there was no closed 

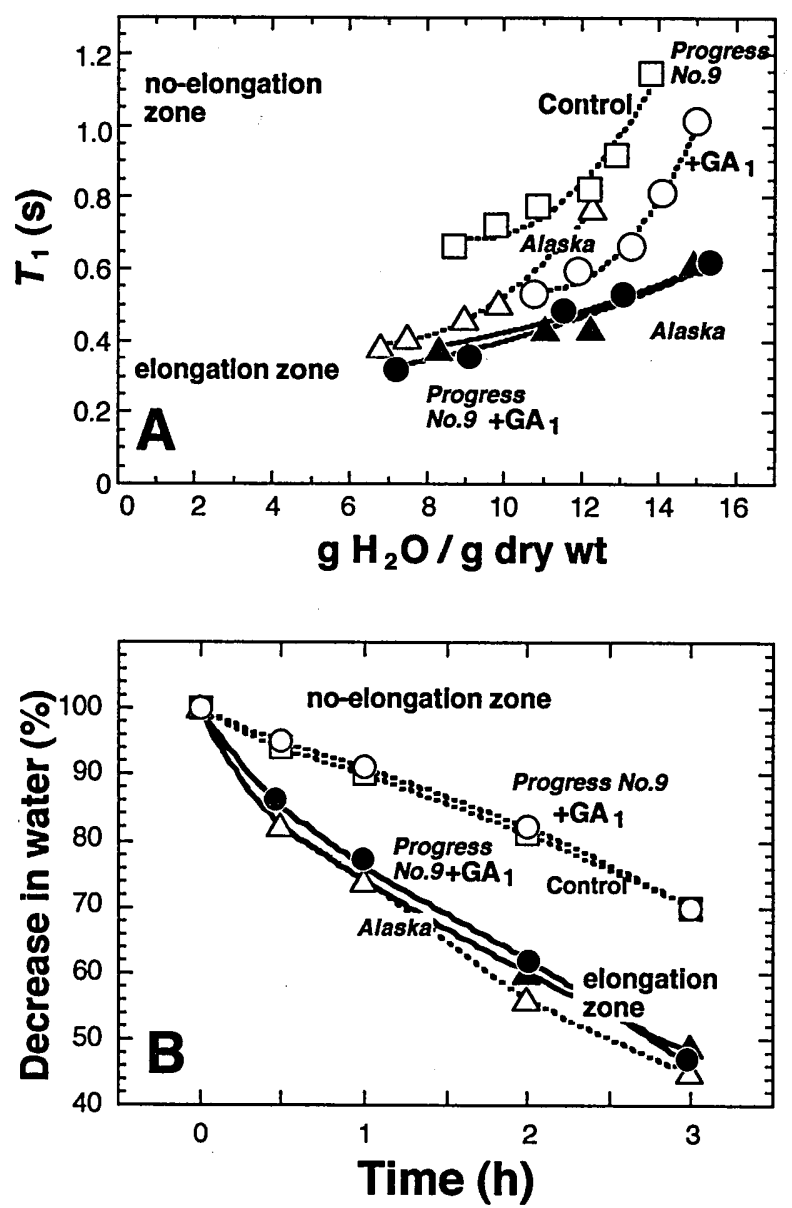

Fig. 3. Influence of air-drying on water content and water status in pea cultivars grown light condition. (A) Relationship between water content and $T_{1}$. Elongation zone $(\boldsymbol{\Delta})$ and no-elongation zone $(\Delta)$ of $\mathrm{cv}$. Akaska; $\mathrm{GA}_{1}$-treated elongation zone (O) and $\mathrm{GA}_{1}$-treated no-elongation zone (O) and control $(\square)$ of Progress No. 9. (B) Time course of water loss in epicotyls of pea cultivars. Symbols are Shown in Fig. 3A.

relationship between osmotic concentration and cortex cell length. On the other hand, it has been reported that GA enhanced cell elongation by increasing cell wall extensibility, osmotic concentration being kept unchanged by starch degradation using a dwarf mutant of rice (Oryza sativa L. cv. Tan-ginbozu) (Matsukura et al., 1998). Dwarf type of sunflower (Helianthus annuus L.) cultivars had up to about $0.4 \mathrm{MPa}$ lower osmotic potential at full turgor compared with a tall cultivar. That is, dwarf sunflower cultivars 


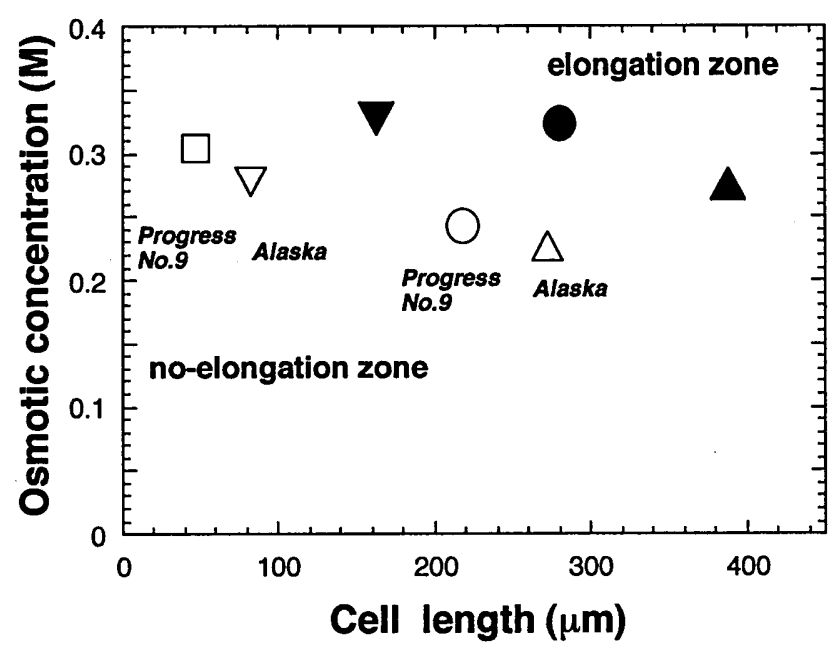

Fig. 4. Relationship between cortex parenchyma cell length and osmotic value of pea cultivars. Open symbols indicate no-elongation zone of cv. Alaska grown under light condition $(\nabla)$ and dark condition $(\Delta)$, no-elongation zone of cv. Progress No. 9 grown under light condition ( $\square)$ and dark condition $(O)$; Closed symbols indicate elongation zone of cv. Alaska grown under light condition ( $\boldsymbol{\nabla}$ ) and dark condition $(\boldsymbol{A})$, and elongation zone of cv. Progress No. 9 grown under dark condition (O).

have ability of greater osmotic adjustment per unit decrease in leaf water potential than the tall cultivar (Angadi and Entz, 2002). Our results suggested that since water contents of both elongation and no-elongation zone were in the same range (Fig. 2), turgor pressure in no-elongation zone might be smaller than those in elongation zone. Generally, $T_{1} \mathrm{~S}$ and water content of azalea florets gradually decreased during cold acclimation (Kaku et al., 1984). Further, cold-acclimated azalea petal tissues had high osmotic concentration and thus it seems that the azalea species have a native adaptability as a high mountain species to a cold environment (Kaku et al., 1982). $T_{1}$ and $T_{2}$ of the sugar solutions linearly depended on their concentrations (Iwaya-Inoue et al., 2002). Therefore, low osmotic concentration in no-elongation zone would partly cause prolongation of $T_{1}$ value in dwarf pea.

In conclusion, water status determined by NMR relaxation times $\left(T_{1} \mathrm{~s}\right)$ in seedling will be useful for a comparative evaluation of the dwarfism and GA dose-response to drought stress. The method revealed that the epicotyl tissues of dwarf type of pea have high $T_{1}$ values accompanied by low osmotic values while water uptake was not changed.

\section{ACKNOWLEDGMENTS}

Seeds of pea cv. Progress No. 9 were kindly provided by Prof. Masayuki Katsumi, 
(Emeritus), International Christian University.

\section{REFERENCES}

Angadi, S. V. and M. H. Entz 2002 Water relations of standard height and dwarf sunflower cultivars. Crop Sci., 42: 152-159

Burke, M. J., R. G. Bryant and C. J. Weiser 1974 Nuclear magnetic resonance of water in cold acclimating red osier dogwood stem. Plant Physiol., 54: 392-398

Cowling, R. J. and N. P. Harberd 1999 Gibberellins control Arabidopsis hypocotyl growth via regulation of cellular elongation. J. Exp. Bot., 50: 1351-1357

Farrar, T. C. and E. D. Becker 1971 Pulse and Fourier Transform NMR. Academic Press, New York (U.S. A.)

Guerrero, F. D. and J. E. Mullet 1988 Reduction of turgor induceds rapid changes in leaf translabale RNA. Plant Physiol., 88: 401-408

Guerrero, F. D., J. T. Jones and J. E. Mullet 1990 Turgor-responsive transcription and RNA levels increase rapidly when pea shoots are wilted. Sequence and expression of threc inducible genes. Plant Molec. Biol. 15: 11-26

Hays, D. B., E. C. Yeung and R. P. Pharis 2002 The role of gibberellins in embryo axis development. J. Exp. Bot., 53: 1747-1751

Huang, B. R. and F. J. B. Wang 1998 Water relations and canopy characteristics of tall fescue cultivars during and after drought stress. HortScience., 33: 837-840

Ikeda, T., H. Nonami, T. Fukuyama and Y. Hashimoto 1999a. Hydraulic contribution in cell elongation of tissue-cultured plants: Growth retardation induced by osmotic and temperature stresses and addition of 2,4-dichlorophenoxyacetic acid and benzylaminopurine. Plant Cell Environ., 22: 899-912

Ikeda, T., H. Nonami, T. Fukuyama and Y. Hashimoto 1999b. Water potential associated with cell elongation and cell division of tissue-cultured carnation plants. Plant Biotechnol., 16: 115-121

Ishida, N., M. Koizumi and H. Kano 2000 The NMR microscope: unique and promising tool for plant science. Ann. Bot. 86: 259-279

Iwaya-Inoue, M., K. Yoshimura, H. Yamasaki and S. Kaku 1993 Characteristic changes in relaxation times of water protons in Vigna radiata seedlings exposed to temperature stress. Plant Cell Physiol., 34: 705-711

Iwaya-Inoue, M., R. Matsui, M. Fukuyama and K. Sakaguchi 2002 Changing point of chilling sensitivity in Arrhenius plots of NMR relaxation times $\left(T_{1}, T_{2}\right)$ in sweet potato tubers. Cryobiol. Cryotechnol., 48 : 101-108

Iwaya-Inoue, M. and H. Nonami 2003 Effects of trehalose on flower senescence from the view point of physical states of water. Environ. Cont. Biol., 41: 3-15

Kaku, S., M. Iwaya and K. B. Jeon 1982 Supercooling ability and cold hardiness of Rhododendron flower buds with reference to winter water relations. In "Plant Cold Hardiness and Freezing Stress" Vol. 2 ed. by P. H. Li and A. Sakai, Academic Press, Inc., New York, pp. 357-366

Kaku, S., M. Iwaya-Inoue and L. V. Gusta 1984 Relationships of nuclear magnetic resonance relaxation time to water content and cold hardiness in flower buds of evergreen azalea. Plant Cell Physiol., 25: $875-882$

Kaku, S., and M. Iwaya-Inoue 1990 Factors affecting the prolongation of NMR relaxation times of water protons in leaves of woody plants affected by formation of insect galls. Plant Cell Physiol., 31: 627-637

Kaku, S., M. Iwaya-Inoue and K. Toki 1992 Anthocyanin influence on water proton NMR relaxation times and water contents in leaves of evergreen woody plants during the winter. Plant Cell Physiol., 33: $131-137$

Kaku, S. and M. Iwaya-Inoue 1990 Factors affecting the prolongation of NMR relaxation times of water protons in leaves of woody plants affected by formation of insect galls. Plant Cell Physiol., 31: 627-637

Kato-noguchi, H. and T. Hashimoto 1997/98 Changes in concentration of endogenous growth inhibitors during growt recovery of dwarf pea seedlings. Biol. Plant., 40: 75-79

Kato-Noguchi, H. 2002 Effects of red light on gibberellin $3 \beta$-hydroxylase gene expression in dark-grown 
seedlings of dwarf and tall cultivars of Pisum sativum J. Plant Physiol., 159: 607-612

Lockhart, J. A. 1965a An analysis of irreversible plant cell elongation. J. Theor. Biol., 8: 264-275

Lockhart, J. A. 1965b Cell extension. In "Plant Biochemistry", ed. by J. Bonner and J. E. Varner, Academic Press, Inc., New York, pp. 826-849

Matsukura, C., S. Itoh, K. Nemoto, E. Tanimoto, J. Yamaguchi 1998 Promotion of leaf sheath growth by gibberellic acid in a dwarf mutant of rice. Planta, 205: 145-152

Molz, F. J. and J. S. Boyer 1978 Growth-induced water potentials in plant cells and tissues. Plant Physiol., 62: 423-429

Noguchi, H. and T. Hashimoto 1990 Phytochrome-mediated synthesis of novel growth inhibitors, A-2 $\alpha$ and $\beta$, and dwarfism in peas. Planta, 181: 256-262

Nonami, H. and J. S. Boyer 1987 Origin of growth-induced water potential: Solute concentration is low in apoplast of enlarging tissues. Plant Physiol., 83: 596-601

Nonami, H and J. S. Boyer 1993 Direct demonstration of growth-induced water potential gradient. Plant Physiol., 102: 13-19

Nonami H., Y. Wu and J. S. Boyer 1997 Decreased growth-induced water potential: A primary cause of growth inhibition at low water potentials. Plant Physiol., 114: 501-509

Sponcel, V. M. 1986 Gibberellins in dark-and light-grown shoots of dwarf and tall cultivars of Pisum sativum. Planta, 168: 119-129

Yoshida, M., J. Abe, M. Moriyama, S. Shimokawa and Y. Nakamura 1997 Seasonal changes in the physical state of crown water associated with freezing tolerance in winter wheat. Physiol. Plant., 99: 363-370 